\title{
Faktor- Faktor yang Berhubungan dengan Kejadian Hipertensi pada Lansia di Puskesmas Air Dingin Lubuk Minturun
}

\author{
Imelda ${ }^{1}$, Fidiariani Sjaaf, $\mathrm{F}^{2}$, Puspita PAF, $\mathrm{T}^{3}$ \\ ${ }^{1}$ Mahasiswa Fakultas Kedokteran Universitas Baiturrahmah, Padang, Indonesia \\ e-mail: imeldamansur17@gmail.com \\ ${ }^{2}$ Bagian Kesehatan Masyarakat, Fakultas Kedokteran Universitas Baiturrahmah, Padang, Indonesia \\ e-mail: Vidiariani@gmail.com \\ ${ }^{3}$ Bagian Dermatovenereology, Fakultas Kedokteran Universitas Baiturrahmah, Padang, Indonesia \\ e-mail: tripuspita@fk.unbrah.ac.id
}

\begin{abstract}
Abstrak
Latar belakang: Hipertensi merupakan salah satu penyakit tidak menular yang menjadi masalah kesehatan sangat serius saat ini dan menjadi penyebab terbesar dari kejadian stroke, baik tekanan darah sistolik maupun diastoliknya. Angka insiden hipertensi sangat tinggi terutama pada populasi lanjut usia. Tujuan: Mengetahui faktor-faktor yang berhubungan dengan kejadian hipertensi pada lansia di Puskesmas Air Dingin Lubuk Minturun. Metode: Penelitian ini merupakan studi analitik dengan rancangan cross sectional dan dilakukan kajian kualitatif dengan wawancara mendalam. Penelitian ini dilakukan di Puskesmas Air Dingin Lubuk Minturun dari bulan Juli hingga November 2019. Sampel yang digunakan berjumlah 110 orang yang diambil secara accidental sampling. Analisa univariat disajikan dalam bentuk tabel distribusi frekuensi sedangkan analisa bivariat menggunakan uji Chi-Square dengan $\alpha=0,05$ dan tingkat kepercayaan 95\%. Hasil: ada hubungan antara tingkat konsumsi garam dengan kejadian hipertensi pada lansia $(\mathrm{p}=0,025)$, ada hubungan antara tingkat konsumsi makanan berlemak dengan kejadian hipertensi pada lansia $(p=0,010)$, tidak ada hubungan antara kebiasaan merokok dengan kejadian hipertensi pada lansia $(\mathrm{p}=0,846)$, tidak ada hubungan antara kebiasaan olahraga dengan kejadian hipertensi pada lansia $(p=0,179)$, tidak ada hubungan antara obesitas dengan kejadian hipertensi pada lansia $(\mathrm{p}=0,980)$, ada hubungan antara tingkat stress dengan kejadian hipertensi pada lansia $(p=0,011)$, tidak ada hubungan antara status sosial ekonomi dengan kejadian hipertensi pada lansia $(p=0,101)$. Kesimpulan: Terdapat hubungan antara kebiasaan asupan garam dengan kejadian hipertensi pada lansia di Puskesmas Air Dingin Lubuk Minturun. Terdapat hubungan antara kebiasaan konsumsi makanan berlemak dengan kejadian hipertensi pada lansia di Puskesmas Air Dingin Lubuk Minturun. Tidak terdapat hubungan antara kebiasaan merokok dengan kejadian hipertensi pada lansia di Puskesmas Air Dingin Lubuk Minturun. Tidak terdapat hubungan antara kebiasaan olahraga dengan kejadian hipertensi pada lansia di Puskesmas Air Dingin Lubuk Minturun. Tidak terdapat hubungan antara obesitas dengan kejadian hipertensi pada lansia di Puskesmas Air Dingin Lubuk Minturun. Terdapat hubungan antara stres dengan kejadian hipertensi pada lansia di Puskesmas Air Dingin Lubuk Minturun. Tidak terdapat hubungan antara status sosial ekonomi dengan kejadian hipertensi pada lansia di Puskesmas Air Dingin Lubuk Minturun.
\end{abstract}

Kata kunci: Hipertensi, Lansia

\section{Abstract}

Background: Hypertension is a non-communicable disease which is a very serious health problem today and is the biggest cause of stroke, both systolic and diastolic blood pressure. The incidence of hypertension is very high especially in the elderly population. Objective: $t$ To determine the factors associated with the incidence of hypertension in the elderly at the Lubuk Minturun Air Dingin Health Center. Method: This research is an analytic study with cross sectional design and conducted a qualitative study with in-depth interviews. This research was conducted at the Air Dingin Lubuk Minturun Health Center from July to November 2019. The sample used was 110 people taken by accidental sampling. Univariate analysis is presented in the form of a frequency distribution table while bivariate analysis uses the Chi-Square test with $\alpha=0.05$ and a confidence level of 95\%. Results: there is a correlated between the level of salt consumption with the incidence of hypertension in the elderly $(p=0.025)$, there is a relationship between the level of consumption of fatty foods

Email : heme@ unbrah.ac.id 
with the incidence of hypertension in the elderly $(p=0.010)$, there is no correlated between smoking habits with the incidence of hypertension in the elderly elderly $(p=0.846)$, there is no correlated between sports habits with the incidence of hypertension in the elderly $(p=0.179)$, there is no correlated between obesity and the incidence of hypertension in the elderly $(p=0.980)$, there is a correlated between the level of stress with the incidence of hypertension in the elderly $(p=0.011)$, there was no correlated between socioeconomic status and the incidence of hypertension in the elderly $(p=0.101)$. Conclusion: There is a relationship between the habit of salt intake and the incidence of hypertension in the elderly at Air Cold Lubuk Minturun Health Center. There is a relationship between the habit of consuming fatty foods with the incidence of hypertension in the elderly at Air Cold Lubuk Minturun Health Center. There is no relationship between smoking habits and the incidence of hypertension in the elderly at Air Cold Lubuk Minturun Health Center. There is no relationship between exercise habits and the incidence of hypertension in the elderly at Air Cold Lubuk Minturun Health Center. There is no relationship between obesity and the incidence of hypertension in the elderly at Air Cold Lubuk Minturun Health Center. There is a relationship between stress and the incidence of hypertension in the elderly at Air Cold Lubuk Minturun Health Center. There is no relationship between socioeconomic status and the incidence of hypertension in the elderly at Air Cold Lubuk Minturun Health Center.

Keywords: Hypertension, Elderly

\section{Pendahuluan}

Pembangunan kesehatan di Indonesia merupakan upaya kesehatan untuk mencapai kemampuan hidup sehat bagi setiap penduduk dalam mewujudkan derajat kesehatan yang optimal. Keberhasilan pemerintah dalam bidang medis mampu meningkatkan kualitas kesehatan penduduk dan Usia Harapan Hidup (UHH). Hal ini dapat dilihat dari bertambahnya jumlah penduduk dengan usia lanjut di Indonesia. ${ }^{1}$

Hipertensi merupakan salah satu penyakit tidak menular yang menjadi masalah kesehatan yang sangat serius saat ini. Hipertensi yang tidak terkontrol dapat menyebabkan peluang 7 kali lebih besar terkena stroke, 6 kali lebih besar terkena penyakit jantung kongestif, dan 3 kali lebih besar terkena serangan jantung. ${ }^{2}$

Pada kebanyakan kasus, hipertensi terdeteksi saat dilakukan pemeriksaan fisik karena alasan penyakit tertentu, sehingga sering disebut sebagai silent killer. Hipertensi merupakan penyakit yang mendapat perhatian dari semua kalangan masyarakat, sehingga membutuhkan penanggula-ngan jangka panjang yang menyeluruh dan terpadu. $^{3}$

Data Global Status Report on Noncommunicable Diseases 2010 dari World Health Organization (WHO) menyebutkan bahwa jumlah penderita hipertensi pada negara berkembang mencapai $40 \%$, sedangkan di negara maju hanya $35 \%$. Penderita hipertensi usia dewasa di kawasan Asia Tenggara terdiri dari 36\%. Menurut perwakilan WHO untuk Indonesia mengungkapkan bahwa terjadi peningkatan jumlah penderita hipertensi sebesar 13\%, baik pada pria maupun wanita. ${ }^{4}$

Berdasarkan data Dinas Kesehatan Provinsi Sumatera Barat tahun 2017, hipertensi merupakan penyakit dengan jumlah terbanyak ke-3 yang diderita oleh masyarakat. Data pada Puskesmas Air Dingin Lubuk Minturun memperlihatkan bahwa penderita hipertensi yang melakukan pengobatan selama 1 tahun terakhir adalah sebanyak 243 orang dengan kategori umur 60-89 tahun. $^{5}$

Adapun faktor- faktor yang sering menyebabkan terjadinya hipertensi dibagi dalam dua kelompok besar, yaitu faktor yang melekat atau tidak dapat diubah seperti jenis kelamin, umur, genetik dan faktor yang dapat diubah seperti pola makan, kebiasaan olah raga dan lain-lain. ${ }^{1}$

Saat ini terdapat kecenderungan pada masyarakat perkotaan lebih banyak menderita hipertensi dibandingkan masyarakat pedesaan. Hal ini antara lain dihubungkan dengan adanya gaya hidup masyarakat kota yang berhubungan dengan 
risiko hipertensi seperti stres, obesitas (kegemukan), kurangnya olahraga, merokok, alkohol, dan makan makanan yang tinggi kadar lemaknya. Perubahan gaya hidup seperti perubahan pola makan menjurus ke sajian siap santap yang mengandung banyak lemak, protein, dan tinggi garam tetapi rendah serat, membawa konsekuensi sebagai salah satu faktor berkembangnya penyakit degeneratif seperti hipertensi. ${ }^{6}$

Berdasarkan latar belakang di atas, maka perlu dilakukan penelitian untuk mengetahui faktor- faktor yang berhubungan dengan kejadian hipertensi pada lansia di Puskesmas Air Dingin Lubuk Minturun.

\section{Metode Penelitian}

Penelitian ini dibatasi pada faktor-faktor yang berhubungan dengan kejadian hipertensi pada lansia di Puskesmas Air Dingin Lubuk Minturun. Jenis penelitian yang digunakan adalah penelitian analitik kualitatif dengan pendekatan cross sectional, yaitu dengan cara pengumpulan data sekaligus pada suatu waktu dengan tujuan untuk mencari hubungan faktor-faktor yang berhubungan dengan kejadian hipertensi pada lansia di Puskesmas Air Dingin Lubuk Minturun. ${ }^{22}$

Populasi adalah semua lansia penderita hipertensi yang berobat di Puskesmas Air Dingin Lubuk Minturun. Sampel penelitian adalah bagian dari populasi yang memenuhi kriteria inklusi dan eksklusi. Pengambilan sampel dilakukan secara accidental sampling. Kriteria inklusi penelitian ini adalah melakukan pemeriksaan rutin selama 1 tahun terakhir di Puskesmas Air Dingin Lubuk Minturun, bertempat tinggal di lokasi penelitian, bersedia menjadi responden dan dapat berkomunikasi dengan baik. Kriteria eksklusi penelitian adalah lansia yang menderita penyakit penyerta atau komplikasi, alamat tidak jelas atau responden tidak dapat ditemui serta tekanan darah sistol $\geq 140 \mathrm{mmHg}$ dan tekanan darah diastol $\geq 90 \mathrm{mmHg}$.

Alat ukur yang digunakan adalah kuisioner, sphygmomanometer atau tensimeter, stetoskop, kuesioner Perceived Stress Scale 10 (PSS-10) dan metode Food Frequency Quesioner (FFQ) yang digunakan untuk mengetahui konsumsi makanan responden yang mengandung natrium/garam tinggi.

Hasil penelitian dianalisis dengan uji ChiSquare dengan $\alpha=0,05$ dan tingkat kepercayaan $95 \%$.

\section{Hasil Penelitian}

Penelitian dilakukan terhadap sampel yang berjumlah 110 orang yang melakukan pengobatan di Puskesmas Air Dingin Lubuk Minturun.

\section{A. Karakteristik Responden}

\begin{tabular}{llcc} 
TABEL 1: & KARAKTERISTIK & \multicolumn{2}{c}{ RESPONDEN } \\
BERDASARKAN UMUR & & \\
\hline $\begin{array}{c}\text { Karak } \\
\text { teristik }\end{array}$ & \multicolumn{1}{c}{ Kategori } & $\mathbf{N}$ & $\%$ \\
\hline Umur & Virilitas (55-59) & 34 & 30,9 \\
(tahun) & Usia Lanjut Dini (60-64) & 35 & 31,8 \\
& Lansia Resiko Tinggi $(\geq 65)$ & 41 & 37,2 \\
\multirow{2}{*}{ Jenis } & Laki- laki & 51 & 46,3 \\
Kelamin & Perempuan & 59 & 53,6 \\
\hline Total & & $\mathbf{1 1 0}$ & $\mathbf{1 0 0}$ \\
\hline
\end{tabular}

Tabel 1 menunjukkan bahwa responden penelitian paling banyak umur $\geq 65$ tahun yang berjumlah 41 responden atau $37,2 \%$, sedangkan yang paling sedikit adalah kategori umur 55-59 tahun yaitu berjumlah 34 responden atau setara dengan 30,9\%.

Data di atas juga menunjukkan bahwa responden dalam penelitian ini didominasi oleh perempuan yang berjumlah 59 responden atau $53,6 \%$, sedangkan responden laki- laki berjumlah 51 atau setara dengan $46,3 \%$. 


\section{B. Analisis Univariat}

Analisis univariat digunakan untuk melihat gambaran umum dari data yang telah dikumpulkan berdasarkan distribusi frekuensi variabel-variabel penelitian.

TABEL 2. Distribusi FrEKUENSI RESPONDEN BERDASARKAN KEJADIAN HIPERTENSI DI PuSKesmas Air Dingin Lubuk Minturun

\begin{tabular}{llcc}
\hline Variabel & \multicolumn{1}{c}{ Kategori } & n & \% \\
\hline Hipertensi & Normal & 58 & 52,7 \\
& Pra Hipertensi & 52 & 47,3 \\
Konsumsi & Tinggi & 34 & 30,9 \\
Garam & Normal & 76 & 69,1 \\
Konsumsi & Sering & 43 & 39,1 \\
Makanan & Sedang & 65 & 59,1 \\
Berlemak & Jarang & 2 & 1,8 \\
Kebiasaan & Perokok Berat & 25 & 22,7 \\
Merokok & Perokok Sedang & 26 & 23,6 \\
& Perokok Ringan & 25 & 22,7 \\
Kebiasaan & Bukan Perokok & 34 & 30,9 \\
Olahraga & Cukup & 49 & 44,5 \\
& Kurang & 43 & 39,1 \\
Obesitas & Obesitas & 18 & 16,4 \\
& Tidak Obesitas & 39 & 35,5 \\
Tingkat & Tidak Stres & 60 & 64,5 \\
Stres & Stres Ringan & 11 & 54,5 \\
& Stres Sedang & 24 & 21,8 \\
& Stres Berat & 15 & 13,6 \\
Status & Rendah & 45 & 40,9 \\
Sosial & Tinggi & 65 & 59,1 \\
Ekonomi & & & \\
\hline Tabel 2 & menunjukkan bahwa &
\end{tabular}

Tabel 2 menunjukkan bahwa lansia yang menjadi responden lebih banyak mempunyai tekanan darah normal yaitu 58 orang $(52,7 \%)$. Data menunjukkan bahwa lansia dengan konsumsi garam normal berjumlah 76 orang $(69,1 \%)$, konsumsi makanan berlemak yang paling banyak berada pada kategori sedang yaitu 65 orang $(59,1 \%)$. Di samping itu, juga diperoleh hasil bahwa responden didominasi oleh lansia bukan perokok yang berjumlah 34 orang $(30,9 \%)$.

Responden dengan kebiasaan olahraga kategori baik mendominasi atas kategori lainnya yaitu berjumlah 49 orang $(44,5 \%)$ dan tidak mengalami obesitas berjumlah 71 orang $(64,5 \%)$. Dilihat dari tingkat stres, responden yang tidak mengalami stres lebih banyak dibandingkan yang lain yaitu berjumlah 60 orang $(54,5 \%)$ dan memiliki status sosial ekonomi tinggi dengan jumlah 65 orang $(59,1 \%)$.

\section{Analisis Bivariat}

Analisis bivariat dalam penelitian digunakan untuk mengetehui apakah terdapat hubungan yang signifikan antara variabel independen yaitu konsumsi garam, konsumsi makanan berlemak, kebiasaan merokok, kebiasaan olahraga, obesitas, stres, dan status sosial ekonomi dengan variabel dependen yaitu kejadian hipertensi.

Tabel 3. Hasil Analisis Hubungan Beberapa VARIABEL DENGAN KEJADIAN HIPERTENSI

\begin{tabular}{|c|c|c|c|c|c|c|}
\hline \multirow[t]{3}{*}{ Variabel } & \multicolumn{4}{|c|}{ Kejadian Hipertensi } & \multirow{3}{*}{$\begin{array}{l}\text { To } \\
\text { tal }\end{array}$} & \multirow{3}{*}{$\begin{array}{l}\text { P- } \\
\text { Value }\end{array}$} \\
\hline & \multicolumn{2}{|c|}{ Normal } & \multicolumn{2}{|c|}{$\begin{array}{c}\text { Pra } \\
\text { Hipertensi }\end{array}$} & & \\
\hline & $\mathbf{n}$ & $\%$ & $\mathbf{n}$ & $\%$ & & \\
\hline \multicolumn{7}{|l|}{ Konsumsi Garam } \\
\hline - Tinggi & 12 & 35,3 & 22 & 64,7 & 34 & \multirow{2}{*}{0,025} \\
\hline - Normal & 46 & 60,5 & 30 & 39,5 & 76 & \\
\hline \multicolumn{7}{|l|}{$\begin{array}{l}\text { Konsumsi Makanan } \\
\text { Berlemak }\end{array}$} \\
\hline - Sering & 15 & 34,9 & 28 & 65,1 & 43 & \multirow{3}{*}{0,010} \\
\hline - Sedang & 42 & 64,6 & 23 & 35,4 & 65 & \\
\hline - Jarang & 1 & 50,0 & 1 & 50,0 & 2 & \\
\hline \multicolumn{7}{|l|}{ Kebiasaan Merokok } \\
\hline - Perokok Berat & 13 & 52,0 & 12 & 48,0 & 25 & \multirow{4}{*}{0,846} \\
\hline - Perokok Sedang & 13 & 50,0 & 13 & 50,0 & 26 & \\
\hline - Perokok Ringan & 12 & 48,0 & 13 & 52,0 & 25 & \\
\hline - Bukan Perokok & 20 & 58,8 & 14 & 41,2 & 34 & \\
\hline \multicolumn{7}{|l|}{ Kebiasaan Olahraga } \\
\hline - Baik & 23 & 46,9 & 26 & 53,1 & 49 & \multirow{3}{*}{0,179} \\
\hline - Cukup & 22 & 51,2 & 21 & 48,8 & 43 & \\
\hline - Kurang & 13 & 72,2 & 5 & 27,8 & 18 & \\
\hline \multicolumn{7}{|l|}{ Obesitas } \\
\hline - Obesitas & 20 & 51,3 & 19 & 48,7 & 39 & \multirow{2}{*}{0,980} \\
\hline - Tidak Obesitas & 38 & 53,5 & 33 & 46,5 & 71 & \\
\hline \multicolumn{7}{|l|}{ Tingkat Stres } \\
\hline - Tidak Ada Stres & 23 & 38,3 & 37 & 61,7 & 60 & \multirow{4}{*}{0,011} \\
\hline - Stres Ringan & 8 & 72,7 & 3 & 27,3 & 11 & \\
\hline - Stres Sedang & 16 & 66,7 & 8 & 33,3 & 24 & \\
\hline - Stres Berat & 11 & 73,3 & 4 & 26,7 & 15 & \\
\hline
\end{tabular}

Berdasarkan tabel 3 diperoleh hasil bahwa lansia dengan konsumsi garam tinggi lebih banyak mengalami pra hipertensi $(64,7 \%)$ sedangkan lansia dengan konsumsi garam normal memiliki tekanan darah yang normal pula $(60,5 \%)$. Hasil uji statistik (chi- square) diperoleh nilai $\mathrm{p}=0,025(\mathrm{p}<0,05)$, maka dapat disimpulkan bahwa terdapat hubungan antara 
konsumsi garam dengan kejadian hipertensi pada lansia. Dari 110 sampel lansia terdapat $65,1 \%$ yang mengalami pra hipertensi dengan konsumsi makanan berlemak kategori sering. Berdasarkan hasil uji chisquare didapat $\mathrm{p}=0,010 \quad(\mathrm{p}<0,05)$, maka berarti terdapat hubungan antara konsumsi makanan berlemak dengan kejadian hipertensi.

Hasil analisis hubungan antara kebiasaan merokok dengan kejadian hipertensi didapat bahwa terdapat $52,0 \%$ perokok berat dengan tekanan darah normal. Berdasarkan hasil uji chi-square diperoleh $\mathrm{p}=0,846$ ( $\mathrm{p}>0,05)$, hal ini menunjukkan bahwa tidak terdapat hubungan antara kebiasaan merokok dengan kejadian hipertensi pada lansia di Puskesmas Air Dingin Lubuk Minturun.

Tabel 3 menunjukkan bahwa terdapat 53,1\% lansia dengan kebiasaan olahraga baik mengalami pra hipertensi, sedangkan lansia dengan kebiasaan olahraga kurang memiliki tekanan darah normal. Berdasarkan hasil uji chi-square diperoleh $\mathrm{p}=0,179 \quad(\mathrm{p}>0,05)$, maka dapat disimpulkan bahwa tidak terdapat hubungan antara kebiasaan olahraga dengan kejadian hipertensi pada lansia.

Hasil analisis hubungan antara obesitas dengan kejadian hipertensi pada lansia didapat bahwa terdapat $51,3 \%$ lansia dengan obesitas memiliki tekanan darah normal. Hasil uji statistik (chi-square) menunjukkan $\mathrm{p}=0,980(\mathrm{p}>0,05)$, ini berarti tidak terdapat hubungan antara obesitas dengan kejadian hipertensi pada lansia.

Tingkat stres memiliki hubungan dengan kejadian hipertensi pada lansia di Puskesmas Air Dingin Lubuk Minturun, dimana hasil uji chi-square diperoleh $\mathrm{p}=0,011(\mathrm{p}<0,05)$. Hasil analisis hubungan antara status sosial ekonomi dengan kejadian hipertensi diperoleh $p=0,101 \quad(p>0,05)$, sehingga dapat disimpulkan bahwa tidak terdapat hubungan yang signfikan antara keduanya.

\section{Pembahasan}

\section{A. Hubungan Tingkat Konsumsi Garam dengan Kejadian Hipertensi pada Lansia di Puskesmas Air Dingin Lubuk Minturun}

Berdasarkan hasil penelitian terhadap lansia yang berobat di Puskesmas Air Dingin Lubuk Minturun diperoleh bahwa lansia yang paling banyak mengalami pra hipertensi adalah yang mengkonsumsi garam tinggi yaitu sebesar $64,7 \%$. Hasil uji statistik (chi-square) diperoleh $p$-value sebesar 0,025 $(\mathrm{p}<0,05)$ yang berarti tingkat konsumsi garam berhubungan dengan kejadian hipertensi.

Menurut penelitian Dwi Lestari (2007) di Pasar Beringharjo Yogyakarta menunjukkan bahwa pekerja yang banyak mengalami hipertensi adalah pekerja dengan konsumsi garam berlebih yaitu sebesar $75,6 \%$, yang mana diperoleh p-value sebesar 0,000 $(p<0,05)$. Hal ini berarti terdapat hubungan antara tingkat konsumsi garam dengan kejadian hipertensi. ${ }^{7}$ Sejalan pula dengan penelitian yang dilakukan Adriaansz terhadap lansia di Puskesmas Ranomuut Kota Manado (2016), yang mana hasil penelitian menunjukkan bahwa lansia yang mengalami hipertensi didominasi oleh lansia dengan konsumsi garam tinggi yaitu sebesar $62,7 \%$. Hasil uji statistik diperoleh $\mathrm{p}=0,003$ $(\mathrm{p}<0,05){ }^{8}$

Pengaruh asupan garam terhadap hipertensi terjadi melalui peningkatan volume plasma, curah jantung, dan tekanan darah. Konsumsi garam yang dianjurkan tidak lebih dari $6 \mathrm{gr} /$ hari. ${ }^{9}$ Konsumsi garam berlebih memiliki efek langsung terhadap tekanan darah. Semakin tinggi tingkat konsumsi garam seseorang maka semakin tinggi pula prevalensi terjadinya hipertensi.

\section{B. Hubungan Tingkat Konsumsi Makanan Berlemak dengan Kejadian Hipertensi pada Lansia di Puskesmas Air Dingin Lubuk Minturun}


Berdasarkan penelitian diperoleh lansia yang paling banyak mengalami pra hipertensi adalah yang sering mengkonsumsi makanan berlemak yaitu sebanyak $65,1 \%$. Berdasarkan hasil uji statistik diperoleh $p$ sebesar 0,010 dimana $p<0,05$. Hal ini menunjukkan bahwa terdapat hubungan yang signifikan antara konsumsi makanan berlemak dengan kejadian hipertensi pada lansia.

Sejalan dengan penelitian yang dilakukan oleh Stefhany di Posbindu Kelurahan Depok Jaya (2012) bahwa terdapat hubungan antara konsumsi makanan berlemak dengan kejadian hipertensi, dimana $\mathrm{p}=0,010$ ( $\mathrm{p}$ $<0,05$ ) dengan persentase $54,7 \% .{ }^{10}$ Penelitian selanjutnya dilakukan oleh Ramirez di Afrika (2010) yang menunjukkan bahwa terdapat hubungan yang signifikan antara tingkat konsumsi makanan berlemak dengan kejadian hipertensi $(\mathrm{p}=0,024)^{11}$

Lansia yang mengkonsumsi makanan berlemak terlalu sering erat kaitannya dengan peningkatan berat badan yang berisiko terjadinya hipertensi dan juga bisa mengakibatkan penyempitan pembuluh darah karena banyaknya lemak yang menempel pada pembuluh darah yang berujung pada peningkatan tekanan darah.

\section{Hubungan Kebiasaan Merokok dengan Kejadian Hipertensi pada Lansia di Puskesmas Air Dingin Lubuk Minturun}

Berdasarkan hasil uji statistik diperoleh $p$ value sebesar 0,846 ( $\mathrm{p}>0,05)$. Hal ini menandakan bahwa kebiasaan merokok tidak mempunyai hubungan dengan kejadian hipertensi pada lansia. Hasil penelitian ini sejalan dengan penelitian yang dilakukan Hesti Rahayu di Srengseng Sawah Kecamatan Jagakarsa (2012) yang menunjukkan bahwa $65 \%$ perokok berat tidak mengalami hipertensi. Berdasarkan uji statistik diperoleh nilai $\mathrm{p}$ sebesar 1,000 (p $>0,05)^{30}$
Hal ini didukung oleh penelitian Hazellarissa di Posyandu Lansia Selayang Kecamatan Medan Selayang (2017) yang mengemukakan bahwa tidak terdapat hubungan antara kebiasaan merokok dengan kejadian hipertensi $(p=0,287)$. ${ }^{13}$ Namun hasil penelitian tersebut bertolak belakang dengan yang diungkapkan Roslina (2007) bahwa terdapat hubungan antara kebiasaan merokok dengan kejadian hipertensi, dimana hasil uji statistik menunjukkan p-value sebesar $0,046(p<0,05){ }^{14}$

Perbedaan hasil penelitian ini dipengaruhi oleh beberapa faktor diantaranya sebagian besar responden tidak merokok yang berjumlah 34 (30,9\%), hal lainnya adalah sebagian besar merupakan perempuan $(50,99 \%)$.

\section{Hubungan antara Kebiasaan Olahraga dengan Kejadian Hipertensi pada Lansia di Puskesmas Air Dingin Lubuk Minturun}

Berdasarkan penelitian diketahui bahwa kebiasaan olahraga tidak mempunyai hubungan yang signifikan dengan kejadian hipertensi. Hasil uji statistik menunjukkan $p$ value sebesar 0,179 ( $\mathrm{p}>0,005)$.

Hasil penelitian ini sejalan dengan penelitian yang dilakukan Sukmawati di Desa Borimatangkasa Dusun Bontosunggu Kecamatan Bajeng Barat (2016) bahwa kebiasaan olahraga tidak berhubungan dengan kejadian hipertensi. Hasil uji statistik diperoleh $p$-value sebesar $0,567(\mathrm{p}<0,05) .{ }^{13}$

Hasil penelitian ini berlawanan dengan penelitian yang dilakukan Hazellarissa (2017) bahwa proporsi hipertensi lebih tinggi pada lansia dengan kebiasaan olahraga yang kurang yaitu 55,80\%. Hasil uji statistik menggunakan chi-square, diperoleh p-value sebesar $0,028 \quad(p<0,05)$ artinya terdapat hubungan yang signifikan antara kebiasaan olahraga dengan kejadian hipertensi. ${ }^{15}$ 
Penelitian Lina di Puskesmas Demak II tahun 2016 menunjukkan bahwa responden dengan kebiasaan olahraga kurang, lebih banyak mengalami hipertensi yaitu sebesar $87,0 \%$. Hasil uji statistik menggunakan chisquare, diperoleh $p$-value sebesar 0,013 (p $<0,05$ ). Maka dapat disimpulkan bahwa ada hubungan yang signifikan antara kebiasaan olahraga dengan kejadian hipertensi. ${ }^{16}$

Meningkatnya tekanan darah tidak hanya dipengaruhi oleh kebiasaan olahraga, tetapi banyak faktor yang mempengaruhinya seperti jenis kelamin, umur, riwayat keluarga, kebiasaan merokok, dan gaya hidup. Kebiasaan buruk seseorang merupakan ancaman terbesar terhadap kesehatan bagi seseorang seperti gaya hidup yang modern, kerja keras dalam situasi tertekan, dan stres yang berkepanjangan, serta mengatasi stress dengan merokok atau minum minuman yang beralkohol, atau kopi. ${ }^{17}$

\section{E. Hubungan antara Obesitas dengan Kejadian Hipertensi pada Lansia di Puskesmas Air Dingin Lubuk Minturun}

Berdasarkan penelitian dapat dilihat bahwa lansia yang mengalami obesitas tetapi memiliki tekanan darah normal berjumlah $51,3 \%$ dan lansia dengan obesitas yang mengalami pra hipertensi lebih sedikit yaitu sebesar 48,7\%. Hasil uji statistik menggunakan chi-square, diperoleh $p$-value sebesar 0,980 (p>0,05) artinya tidak terdapat hubungan yang signifikan antara obesitas dengan kejadian hipertensi pada lansia.

Penelitian ini sejalan dengan penelitian yang dilakukan Lina pada tahun 2016, yang mana diperoleh $p$-value sebesar 0,272 ( $\mathrm{p}>0,05)$ artinya tidak terdapat hubungan yang signifikan antara obesitas dengan kejadian hipertensi. ${ }^{18}$ Penelitian yang dilakukan oleh Siringoringo dan Hiswani di Desa Sigaol
Simbolon (2013) juga menunjukkan hal yang sama bahwa $p$-value $=0,160 \quad(\mathrm{p}>0,05)$ sehingga dapat disimpulkan tidak terdapat hubungan yang bermakna antara obesitas dengan kejadian hipertensi pada lansia. ${ }^{19}$

Hasil penelitian ini bertolak belakang dengan penelitian yang dilakukan oleh Delmi di Kota Padang tahun 2012. Hasil uji statistik menunjukkan $(\mathrm{p}<0.05)$, hal ini menandakan bahwa terdapat hubungan bermakna antara obesitas dengan kejadian hipertensi. ${ }^{20}$

Obesitas dapat menyebabkan hipertensi karena timbunan lemak akan mempersempit pembuluh darah sehingga aliran darah tidak tercukupi dan jantung harus bekerja lebih keras untuk memenuhi aliran darah yang berdampak pada terjadinya hipertensi. Obesitas bukanlah penyebab hipertensi, namun prevalensi hipertensi pada obesitas jauh lebih besar. $^{29}$

Penderita kasus hipertensi akan mengalami penurunan tekanan darah jika mengurangi asupan garam. Jadi, meskipun seseorang itu memiliki indeks massa tubuh yang underweight atau normal tetapi jika konsumsi natriumnya berlebih maka seseorang memiliki risiko hipertensi.

\section{F. Hubungan antara Tingkat Stres dengan Kejadian Hipertensi pada Lansia di Puskesmas Air Dingin Lubuk Minturun}

Stres merupakan respon fisiologi, psikologi, dan perilaku seseorang untuk penyesuaian diri terhadap tekanan. Stres juga dapat merangsang ginjal melepaskan hormon adrenalin yang menyebabkan tekanan darah naik dan meningkatkan kekentalan darah. ${ }^{30}$

Berdasarkan hasil penelitian diperoleh $p$ value sebesar $0,011(\mathrm{p}<0,05)$ artinya tingkat stres mempunyai hubungan yang signifikan dengan kejadian hipertensi pada lansia.

Hasil dari penelitian ini sejalan dengan penelitian yang dilakukan oleh Andria di 
Posyandu Lansia Kelurahan Gebang Putih Kota Surabaya tahun 2013. Hasil uji statistik menunjukkan $p$-value sebesar $0,012(\mathrm{p}<0,05)$ yang berarti terdapat hubungan yang signifikan antara stres dengan kejadian hipertensi. ${ }^{22}$

Penelitian selanjutnya dilakukan Eva Purwati di Puskesmas Suli Kabupaten Luwu tahun 2018 diperoleh p-value sebesar 0,007 $(\mathrm{p}<0,05)$. Dengan demikian dapat disimpulkan bahwa terdapat hubungan yang bermakna antara stress dengan kejadian hipertensi. ${ }^{23}$

Hal yang perlu diperhatikan terkait variabel stres adalah adanya bias informasi, seperti responden merasa malu dan tidak jujur pada saat menjawab kuesioner serta bias waktu karena ketika dilakukan pengumpulan data, responden sedang tidak mengalami stres atau masalah tertentu yang dapat menimbulkan terjadinya stres berkepanjangan.

\section{G.Hubungan antara Status Sosial Ekonomi dengan Kejadian Hipertensi pada Lansia di Puskesmas Air Dingin Lubuk Minturun}

Berdasarkan penelitian diperoleh p-value sebesar 0,101 $(\mathrm{p}<0,05)$ artinya tidak terdapat hubungan yang bermakna antara status sosial ekonomi dengan kejadian hipertensi.

Penelitian ini sejalan dengan penelitian yang dilakukan oleh Indrawan di Surakarta tahun 2014, dimana hasil uji statistik menggunakan chi-square diperoleh $p$-value sebesar 0,5888 $(\mathrm{p}>0,05)$ yang artinya status sosial ekonomi tidak berhubungan dengan kejadian hipetensi. $^{24}$

Penelitian ini bertolak belakang dengan penelitian yang dilakukan Khanam di Bangladesh tahun 2015 yang menunjukkan bahwa masyarakat pedesaan dengan status sosial ekonomi rendah lebih banyak mengalami hipertensi $(53,5 \%)$ dibandingkan dengan masyarakat kota yang memiliki status sosial ekonomi tinggi (46,5\%). Berdasarkan hasil uji statistik diperoleh $p$ value sebesar $0,001(\mathrm{p}<0,05)$ artinya terdapat hubungan yang signifikan antara status sosial ekonomi dengan kejadian hipertensi. ${ }^{26}$

Penelitian ini sesuai dengan penelitian yang dilakukan Putra di wilayah kerja Puskesmas Sawan II Kabupaten Buleleng tahun 2009. Berdasarkan hasil uji statistik diperoleh $p$ value sebesar 0,040 ( $\mathrm{p}<0,05)$ artinya terdapat hubungan yang signifikan antara status sosial ekonomi dengan kejadian hipertensi. $^{27}$

Kejadian hipertensi sebagian besar terjadi pada kalangan masyarakat dengan status sosial ekonomi rendah. Menurut Dubey salah satu indikator yang paling penting dalam menentukan status sosial ekonomi seseorang adalah dari faktor pendapatan yang bersumber dari sektor formal, informal dan sektor subsistem dalam waktu satu bulan yang diukur berdasarkan rupiah. ${ }^{29}$

Hasil penelitian ini bertentangan dengan teori di atas karena status sosial ekonomi yang tinggi akan berpengaruh pada perubahan gaya hidup yang tidak sehat.

\section{Penutup}

\section{A. Kesimpulan}

Berdasarkan hasil penelitian faktor- faktor yang berhubungan dengan kejadian hipertensi pada lansia di Puskesmas Air Dingin Lubuk Minturun beberapa kesimpulan yang diperoleh adalah:

1. Terdapat hubungan antara kebiasaan asupan garam dengan kejadian hipertensi pada lansia di Puskesmas Air Dingin Lubuk Minturun.

2. Terdapat hubungan antara kebiasaan konsumsi makanan berlemak dengan kejadian hipertensi pada lansia di Puskesmas Air Dingin Lubuk Minturun.

3. Tidak terdapat hubungan antara kebiasaan merokok dengan kejadian hipertensi pada 
lansia di Puskesmas Air Dingin Lubuk Minturun.

4. Tidak terdapat hubungan antara kebiasaan olahraga dengan kejadian hipertensi pada lansia di Puskesmas Air Dingin Lubuk Minturun.

5. Tidak terdapat hubungan antara obesitas dengan kejadian hipertensi pada lansia di Puskesmas Air Dingin Lubuk Minturun.

6. Terdapat hubungan antara stres dengan kejadian hipertensi pada lansia di Puskesmas Air Dingin Lubuk Minturun.

7. Tidak terdapat hubungan antara status sosial ekonomi dengan kejadian hipertensi pada lansia di Puskesmas Air Dingin Lubuk Minturun.

\section{B. Saran}

1. Bagi Masyarakat di Wilayah Puskesmas Air Dingin Lubuk Minturun disarankan perlunya pencegahan terjadinya hipertensi sedini mungkin terutama lansia yang memiliki faktor risiko untuk terjadinya penyakit hipertensi melalui perbaikan pola hidup, pemeriksaan tekanan darah, pengobatan secara rutin, dan menjalani pola hidup yang sehat.

2. Bagi Pelayanan Kesehatan agar perlu meningkatkan peran petugas dalam membimbing lansia untuk mencegah dan meminimalisir kejadian hipertensi dengan mengendalikan faktor risikonya.

\section{DAFTAR PUStaka}

[1] Departemen Kesehatan RI. Pharmaceutical Care untuk Penyakit Hipertensi. Jakarta: Depkes RI; 2006.

[2] Tuminah, RE, Sulistyowati. Prevalensi Hipertensi dan Determinannya di Indonesia. Jakarta: Pusat Penelitian Biomedis dan Farmasi Badan Penelitian Kesehatan Departemen Kesehatan RI; 2009.

[3] Smeltzer SC, Bare BG. Buku Ajar Keperawatan Medikal Bedah Brunner \& Suddarth, edisi 8. Jakarta : EGC; 2002.

[4] Tarigan AR, Zulhaida L, Syarifah. Pengaruh Pengetahuan, Sikap dan Dukungan Keluarga terhadap Diet Hipertensi di Desa Hulu kecamatan Pancur Batu Tahun 2016. Jurnal Kesehatan. 2018; 11 (1): 10-1.
[5] Dinas Kesehatan Provinsi Sumatera Barat. Profil Dinas Kesehatan. 2017.

[6] Arif D. Faktor-Faktor Yang Berhubungan Dengan Kejadian Hipertensi Pada Lansia di Pusling Klumpit UPT Puskesmas Gribig Kabupaten Kudus. Jurnal Ilmiah Kesehatan. 2013; 5 .

[7] Ratnaningsih DL. Faktor- faktor yang Berhubungan dengan Kejadian Hipertensi pada Pekerja Sektor Informal di Pasar Beringharjo Kota Yogyakarta. [Skripsi]. Yogyakarta: Universitas Aisyiyah; 2017.

[8] Adriaansz PN. Hubungan Konsumen Makanan dengan Kejadian Hipertensi pada Lansia di Puskesmas Ranomuut Kota Manado. E- Jurnal Keperawatan. 2016;4:1.

[9] Armilawaty HA, Ridwan A. Hipertensi dan Faktor Risikonya dalam Kajian Epidemiologi. Bagian Epidemiologi. Makassar: Universitas Hasanuddin; 2007.

[10] Stefhany, E. Hubungan Pola Makan, Gaya Hidup dan Indeks Massa Tubuh dengan Hipertensi Pada Pra Lansia dan Lansia di Posbindu Kelurahan Depok Jaya. [Skripsi]. Depok: Universitas Indonesia; 2012.

[11] Ramirez SS, dkk. Prevalence and Correlates of Hypertension: A Cross-Sectional Study among Rural Populations in Sub-Sahran Africa. Journal of Human Hypertension. 2010;24: 786-795.

[12] Rahayu, H. Faktor Risiko Hipertensi pada Masyarakat RW 01 Srengseng Sawah Kecamatan Jagakarsa Kota Jakarta Selatan. [Skripsi]. Depok: Universitas Indonesia; 2012.

[13] Sukmawati. Faktor- faktor yang Berhubungan dengan Kejadian Hipertensi Stadium I dan Stadium II pada Lansia di Desa Borimatangkasa Dusun Bontosunggu Kecamatan Bajeng Barat. [Skripsi]. Makassar: UIN Alauddin; 2016.

[14] Sarasaty. Hubungan Karakteristik (Umur, Jenis Kelamin, Tingkat Pendidikan) dan Aktivitas Fisik dengan Tekanan Darah pada Lansia di Kelurahan Makamhaji Kecamatan Kartasura Kabupaten Sukoharjo. [Skripsi]. Jakarta: UIN Syarif Hidayatullah; 2011.

[15] Asari, HV. Faktor yang Berhubungan dengan Kejadian Hipertensi pada Lansia di Wilayah Kerja Puskesmas PB Selayang II Kecamatan Medan Selayang. [Skripsi]. Medan: Universitas Sumatera Utara; 2017.

[16] Roslina. Analisa Determinan Hipertensi Esensial di Wilayah Kerja 3 Puskesmas Kabupaten Deli Serdang. 2007. [cited 5 Januari 2020]. Available from: http://repository.usu.ac.id/bitstream/123456789/6 783/1/09E0149.pdf

[17] Muhammadun, AS. Hidup Bersama Hipertensi.Yogyakarta; 2010.

[18] Pramana, LDY. Faktor- faktor yang Berhubungan dengan Tingkat Hipertensi di Wilayah Kerja 
Puskesmas Demak II. [Skripsi]. Semarang: Universitas Muhammadiyah; 2016.

[19] Siringoringo M, Hiswani J. Faktor - Faktor Yang Berhubungan dengan Hipertensi pada Lansia di Desa Sigaol Simbolon Kabupaten Samosir Tahun 2013. Jurnal Gizi, Kesehatan Reproduksi dan Epidemiologi. 2013; 2:6.

[20] Delmi S, Elmatris, Rahmi R. Hubungan Obesitas dengan Kejadian Hipertensi pada Masyarakat Etnik Minangkabau di Kota Padang. 2012.[cited 17 November 2019]. Available from: http://mka.fk.unand.ac.id/images/articles/No_2_2 012/hal_188_abstrak.pdf.

[21] Sugiharto A. Faktor-faktor Risiko Hipertensi Grade II pada Masyarakat (Studi Kasus di Kabupaten Karanganyar). 2007. [cited 17 November 2019). Available from: http://eprints.undip.ac.id/16523/1/Aris_Sugiharto. pdf .

[22] Andria KM. Hubungan antara Perilaku Olahraga, Stres dan Pola Makan dengan Tingkat Hipertensi pada Lanjut Usia di Posyandu Lansia Kelurahan Gebang Putih Kecamatan Sukokilo Kota Surabaya. Jurnal Promkes. 2013;1:2.

[23]Eva, PH. Faktor yang Berhubungan dengan Kejadian Hipertensi pada Ibu Hamil di Wilayah Kerja Puskesmas Suli Kabupaten Luwu. [Thesis]. Makasar: Universitas Hasanudin; 2018.

[24] Adhitomo I. Hubungan Antara Pendapatan, Pendidikan dan Aktivitas Fisik Pasien dengan Kejadian Hipertensi. [Thesis]. Surakarta: Universitas Sebelas Maret; 2014.

[25] Finsie LW, Budi TR, Jootje ML. Faktor- faktor yang Berhubungan dengan Kejadian Hipertensi pada Pasien Rawat Jalan di Puskesmas Ratahan Kabupaten Minahasa Tenggara Periode Desember 2013- Mei 2014. [Skripsi]. Manado: Universitas Sam Ratulangi; 2014.

[26] Khanam, MA. Prevalence and Determinants of Pre Hypertension and Hypertension among The Adults in Rural Bangladesh: Findings from A Community- Based Study. 2015.

[27] Putra MM. Hubungan Keadaan Sosial Ekonomi dan Tingkat Stres dengan Kejadian Hipertensi. Jurnal Ilmiah Keperawatan, 2019;7:2.

[28] Dubey RK. et al. Effect of Contemporary Lifestyle and Socioeconomic Status on Hypertension in Eastern U.P., India. International Research Journal of Pharmacy. 2014;4:12.

[29] Sustrani L. Hipertensi. Jakarta: PT. Gramedia Pustaka Utama; 2004.

[30] Cahyono S. Gaya Hidup dan Penyakit Modern. Jakarta: Kanisius; 2008. 